\title{
Micropalaeontological and Geochemical Evidence of the Late Jurassic Radiolarians Cherts of Naga Ophiolite Hill, Nagaland, Northeast-India
}

\author{
Ramamoorthy Ayyamperumal1,2* ${ }^{\mathbb{C}}$, Ramasamy Sooriamuthu ${ }^{2}$, \\ Gnanachandrasamy Gopalakrishnan ${ }^{3}$, Ganga Biswa ${ }^{4}$, Rajkumar Perumal5, \\ Prerna Gahlaut6, Nusrat Nazir ${ }^{7}$, Justine Kandathil Antony ${ }^{8}$
}

${ }^{1}$ MOE Key Laboratory of Western China's Environmental System, College of Earth and Environmental Sciences, Lanzhou University, Lanzhou, China

${ }^{2}$ Department of Geology, University of Madras, Chennai, India

${ }^{3}$ School of Geography and Planning, Sun Yat-sen University, Guangzhou, China

${ }^{4}$ Department of Geology, Mohanlal Sukhadia University, Udaipur, India

${ }^{5}$ Centre for Earth Sciences, Indian Institute of Science, Bangalore, India

${ }^{6}$ Department of Geology, Hemwati Nandan Bahuguna Garhwal University, Srinagar, India

${ }^{7}$ School of Earth Sciences, Lanzhou University, Lanzhou, China

${ }^{8}$ Department of Earth Sciences, Annamalai University, Chidambaram, India

Email: ^ramamoorthy@lzu.edu.cn

How to cite this paper: Ayyamperumal, R., Sooriamuthu, R., Gopalakrishnan, G., Biswa, G., Perumal, R., Gahlaut, P., Nazir, N. and Antony, J.K. (2021) Micropalaeontological and Geochemical Evidence of the Late Jurassic Radiolarians Cherts of Naga Ophiolite Hill, Nagaland, Northeast-India. Open Journal of Geology, 11, 356-372. https://doi.org/10.4236/ojg.2021.118019

Received: June 9, 2021

Accepted: August 10, 2021

Published: August 13, 2021

Copyright $\odot 2021$ by author(s) and Scientific Research Publishing Inc. This work is licensed under the Creative Commons Attribution International License (CC BY 4.0).

http://creativecommons.org/licenses/by/4.0/ (c) (i) Open Access

\begin{abstract}
We analyzed the radiolarian assemblages (pelagic sediments) and geochemical studies of 15 samples collected from Meluri district Nagaland, Naga Hills Ophiolite belt (NHO) and it consists of the Flysch Naga-Arakan-Yoma trough beyond the Indo-Myanmar border. It reflects one of the many components of the Himalayan Orogenic systems of Tethyan oceanic crust discovered in Nagaland at Meluri district of India and they have very well-preserved studies and can be identified to Upper Jurassic (Kimmeridgian-mid-Tithonian). As well as a continuous sequence of Kimmeridgian-mid-Tithonian, five radiolarian assemblages have been identified in this study. This is so far the first recovery of pelagic sediment assemblages (Radiolarians) from the Naga Hills Ophiolite complex. Samples of Naga Hills Ophiolite belts fell in the Sublitharenite, Litharenite, and $\mathrm{Fe}$-shale $\mathrm{Fe}-$ sand area, and the $\mathrm{A}-\mathrm{CN}-\mathrm{K}$ diagram indicates that these sediments in the source region were exposed deep to moderate weathering conditions. In the discriminant plot, the Naga Hill-OphioliteChert samples occupy the field of origin of the sediment quartzose, and the $\log \left(\mathrm{K}_{2} \mathrm{O} / \mathrm{Na}_{2} \mathrm{O}\right)$ versus $\mathrm{SiO}_{2}$ samples fall into the active continental marginal
\end{abstract}


field, and only one sample falls into an island arch, suggesting that the tectonic framework of the Naga Hills-Chert samples was deposited in the active continental margin and the diagrams $\mathrm{K}_{2} \mathrm{O} / \mathrm{Al}_{2} \mathrm{O}_{3}$ and $\mathrm{MgO} / \mathrm{Al}_{2} \mathrm{O}_{3}$ illustrated the tectonic setting of the marine environment from Naga Hill Ophiolite Chert. Such findings have been consistent with the current geology of Naga Hills in the province of Nagaland.

\section{Keywords}

Geochemistry, Late Jurassic, Radiolarians, Naga Hill Ophiloite, Northeast Nagaland India

\section{Introduction}

The NE-SW Naga Hills in the northeastern region of the Indo-Myanmar Ranges (IMR) at Manipur, Nagaland, regions of Arunachal Pradesh, and neighboring Western Myanmar states, Myanmar and central part of the mountainous region have been recognized as a small arcuate area for the formation of ophiolite [1]. Naga Ophiolite is a succession of strongly deformed and tectonized ophiolitic rocks that have formed in the Nagaland and Manipur northeastern provinces. The Naga-Andaman suture passes through West Burma at the northeastern end of such a large collection of authorities, which flows over more than 3000 kilometers from NE India to the Andaman Island in the Ocean [2] [3] [4]. The NHO consisted of serpentinized peridotite dismembered bodies, mafia-ultramafic deposits, volcanic mafic, pyroclastic, oceanic sediments, and high-pressure metamorphoses along with glaucophane bearing meta basics, and cherts [1]. The Naga Hills, in northeastern India, represents the northern segment of the N-S trend in the Indo-Burmese Range (IBR), which is generally recognized as an extension of the Andaman-Indonesian island arc. Further north, the Naga Hills have connected to the eastern end of the Himalayas [4] and a narrow path from the late Mesozoic to early Paleogene.

The ophiolitic rocks are situated at the northern edge of the Himalayas and the east side of the Indo-Burmese range, then proceed to a submarine sub arch of the Indonesian arch system, toward the south, towards the islands of Andaman-Nicobar-Mentawi. In Naga Hills and the Andaman Islands, ophiolitic rocks are in occurring as stacks of thrust. Even at close intervals, the 69 various parts of the dismembered suite are often difficult to correlate. Such parts are exposed and appear around a specific belt that holds a strong tectonic and a typical position in the centre of open Synformal Klippen. The ophiolite belts are approximately 200 kilometers long and relatively broad in its northern Nagaland. A number of deep-sea deposits, such as chert, carbonaceous mudstone, fine-grained sandstone, and the Naga Ophiolite itself, are driven westward by the formation of Disang and it is pressed out over to the super young Paleogene's to the west. Both higher growth areas have been assigned mostly to Upper Eocene [5]. In the 
appearance of Nummulite sp., the natural gas horizon was moved from Disang formations (Upper Eocene) and this biostratigraphic study was recently verified by Uddin [6]. According to the Disang Formation, other regions of Nagaland are divided into a range of sandy beds with Oligocene fragments for plants [7] [8] [9].

The previous study by [2] [8] [9] [10] [11] [12] results of the biostratigraphy of the Nagaland Ophiolite radiolarian location is summarized in Cretaceous foraminifera, calcareous Nano fossil, and six positions in Nagaland radiolarian assemblages. Unfortunately, photomicrographs are of poor quality and a large proportion of the dinosaur bones have been classified from genus-level inner chapters [10]. The ages allocated to these assemblages indicate that in this section of the Neotethyan Sea there are deep-sea requirements. In every tectonic study, it is necessary to better understand the life of the sea associated with the collapse of Gondwana and enabling the emergence of the Neotethyan Ocean.

The research paper provides an informative characteristic of the deep marine sediments of pelagic red Chert samples from the Naga Hills Ophiolite Belt, to determine their period (era) within the Neotethyan Ocean tectonic approach, based on radiolarian assemblages recorded from the study area. In comparison, earlier kinds of research on the geochemistry of the Naga hill in these regions are not available. To date, the Naga hills geochemistry of cherts samples India Nagaland state was not yet explored in detail to define its rock source characteristics, provenance, paleoclimate, and tectonic setting. The research article aims to present evidence of the oceanic pelagic sediments of NHO Red cherts, their tectonic settings, provenance, paleoclimate of the Naga ophiolite complex, Northeast India. We carried out the radiolarian species identification and geochemical analysis of radiolarian cherts to obtain an improved understanding of the biota and age determination from the Naga Ophiolite complex.

\section{Material and Methods}

\subsection{Study Area}

The Naga Ophiolite itself is thrust westwards over the Disang formation, a series of deep-marine deposits including cherts, carbonaceous mudstones, and fine-grained sandstones. The Disang Formation is thrust over younger Paleogene flysch to the west. It has been assigned to the Upper Eocene using foraminifers extracted from the upper portions of the formation. [5] assigned a shale horizon from the Disang Formation to the Upper Eocene, based on the presence of Nummulites sp. Recently, this biostratigraphic work was confirmed by [6]. The present study was performed at the Naga Hills Ophiolite, which is one of Nagaland, Northeast India's four distinct tectonostratigraphic units. Fifteen samples have been collected at Zipu and Mokie Village in the Meluri district, Nagaland (Figure 1). Various lithologies such as limestones, cherts, spillites, and many other volcanic rocks of ophiolite-derived sediments have been formed. All the samples collected from the Pelagic oceanic sediments of feebly metamorphosed red chert samples containing radiolarian were concentrated for the present study. 


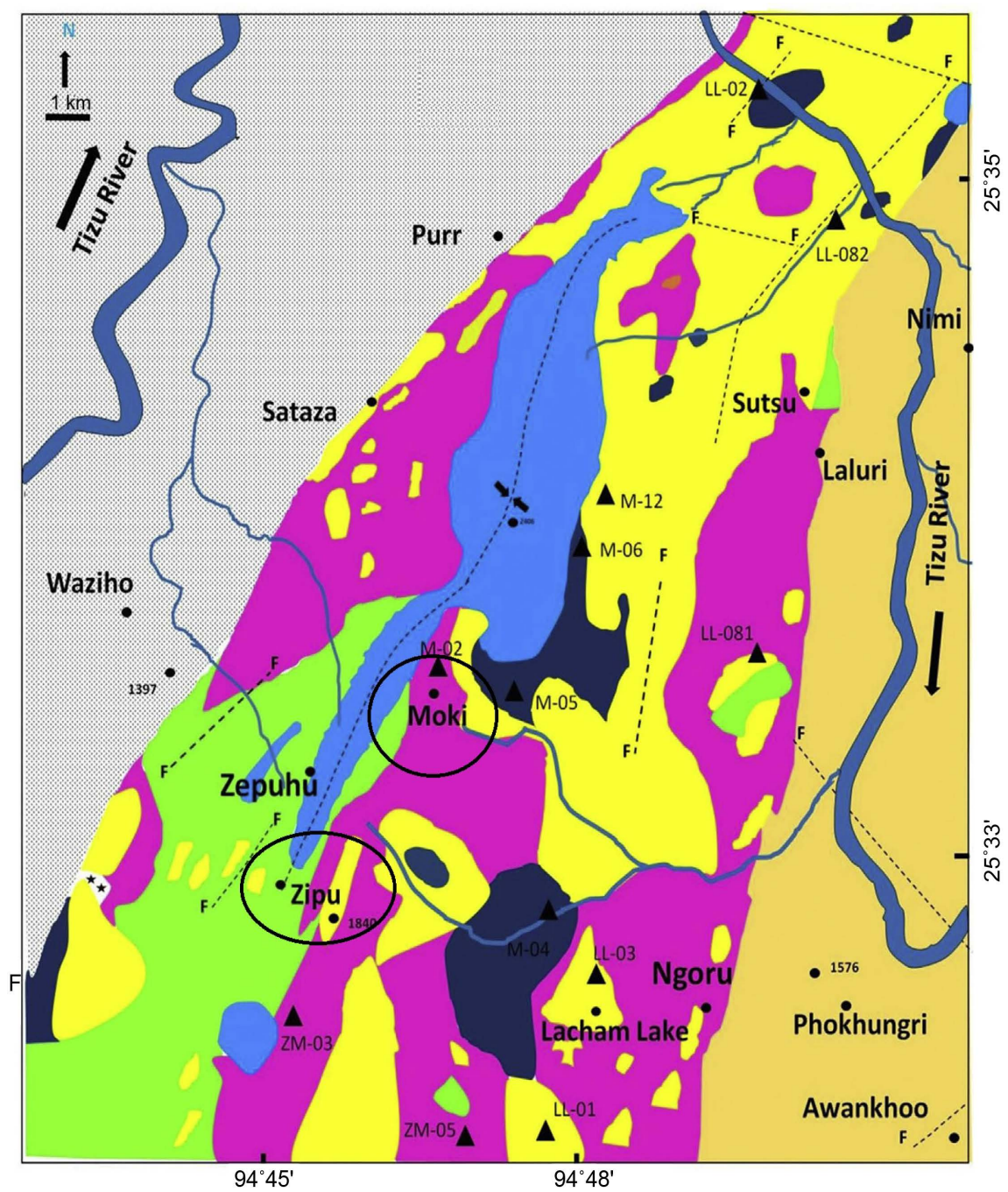

Figure 1. Location map of the study area.

\subsection{Laboratory Procedures}

Fifteen samples were taken from the Mokie and Zipu roadside areas and we followed the methods of [13] to perform radiolarian analyses. Red chert samples were collected and evaluated for various geochemical and Micropaleontological studies. A Chert sample fragment is etched with concentrated hydrofluoric acid $(52 \%-55 \%)$ for three to five minutes, removed from the acid and washed briefly but carefully with water and then with a stone mill or ground a steel mortar and pestle in fragments of $1 \mathrm{~cm}$ up to $5 \mathrm{~cm}$. The crushed chert is placed in beakers with diluted HF acid (nine parts of water to one part of acid) for 24 hours. Radiolarian analyses were identified and extracted from the dried residues under a stereomicroscope and thereafter photograph with an SEM. The identified radiolarian species were later scanned and taken with SEM images from IIT, Chennai. For geochemistry, all the samples were selected from the cherts for preparation of laboratory works and analyzed using XRF instruments at the University of Madras, Chennai. Ten samples of the major and trace geochemical elements 
have been analyzed. Perhaps every sample collected has been salted into an agate mortar and heavy metal particles have been analyzed of the major elements of the PW 2404 Rhodium X-ray fluorescence spectrometer [13] [14]. Every sample has been analyzed three times and the results were compared. The LOI has been evaluated by a pre- and post-calcination weight of $1 \mathrm{~h}$ at $1000^{\circ} \mathrm{C}$. The digested mixture of Hydro Fluoric acid, Sulphuric acid, and $\mathrm{HclO}_{4}$ reagent is completely dissolved.

\section{Results and Discussions}

\section{Radiolarians Identification, Accumulation, and Age Obligation}

Radiolarians, the primary sediment-producing organisms, are abundant in all varieties of cherts exposed in this present study, but they are often affected or destroyed by diagenetic dissolution in the middle part of individual beds and are usually better preserved close to the bedding surfaces of chert layers. Their concentrations accentuate fine lamination, which is disrupted occasionally by bioturbation [2] [5]. We have been identified a total of five radiolarians taxa from the pelagic sediments of the study area and dominated the species of Zhamoidellum ovum dumitrica, Gongylothorax favosus dumitrica, Williriedellum crystallinum dumitrica, Hiscocapsa sp. Verbeeki and Holocryptocanium sp. dumitrica. The preservation of radiolarians was good excellent in all samples (Plates 1-3). It has been identified from the late Jurassic radiolarians of the NHO complex [15] [16]. The present research work on the radiolarian assemblages and their distribution in Naga Hills Ophiolite was carried out on the basis of morphological characteristic features and the previous work published literature carried out by [17] [18]. Radiolarians were often utilized key attributes of deep-sea sediment deposition in suture zones, which are also of crucial importance for limiting the time of major events. They are commonly used during Neotethyan Ocean researches and thus can be discovered in the sedimentary covering of the seafloor or interspersed with basalt pillows [17]. Some of the important constituents of the recorded radiolarian assemblage of the Naga Hills Ophiolites include Zhamoidellum ovum Dumitrica, gongylothorax favosus dumitrica, Williriedellum crystallinum dumitrica, Hiscocapsa sp. Verbeeki and Holocryptocanium sp. dumitrica as indicated in Plates 1, 2, 3. From the analysis of radiolarian assemblages, NHO determines their age from Jurassic to Cretaceous by [18], and it is determined using the standard proceedings and well-preserved taxa of five (5) radiolarians and found its dominance of age ranging from Kimmeridgian to mid-Tithonian. A biostratigraphic site of the Unitary Association (UA) with areas strongly connected to either the geological time of scale (2004) was evaluated using the very well-established Jurassic to Cretaceous Radiolarians Zoning [19]. Samples indicate that the Kimmeridgian to in the Mid-Tithonian period overlaps with large, well-preserved taxa (Table 1). In that same component including its Naga-Andaman suture zone, the development of the well-preserved 


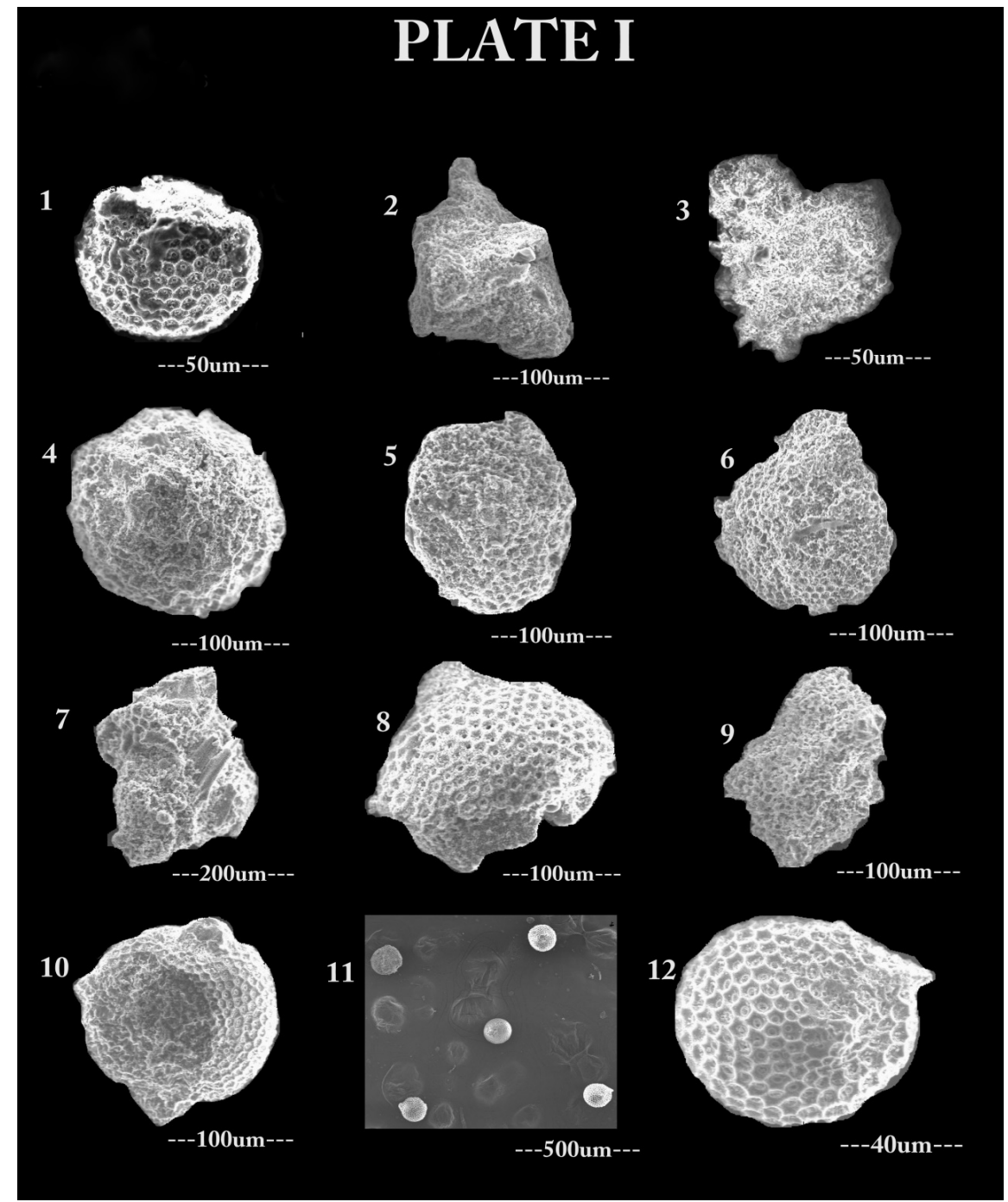

Plate 1. 1. Hiscocapsa sp. Verbeek; 8. Zhamoidellum ovum Dumitrica; 10. Gongylothorax favosus Dumitrica; 12. Gongylothorax favosus Dumitrica.

Table 1. Radiolarian zonation of late jurassic and stratigraphic ranges.

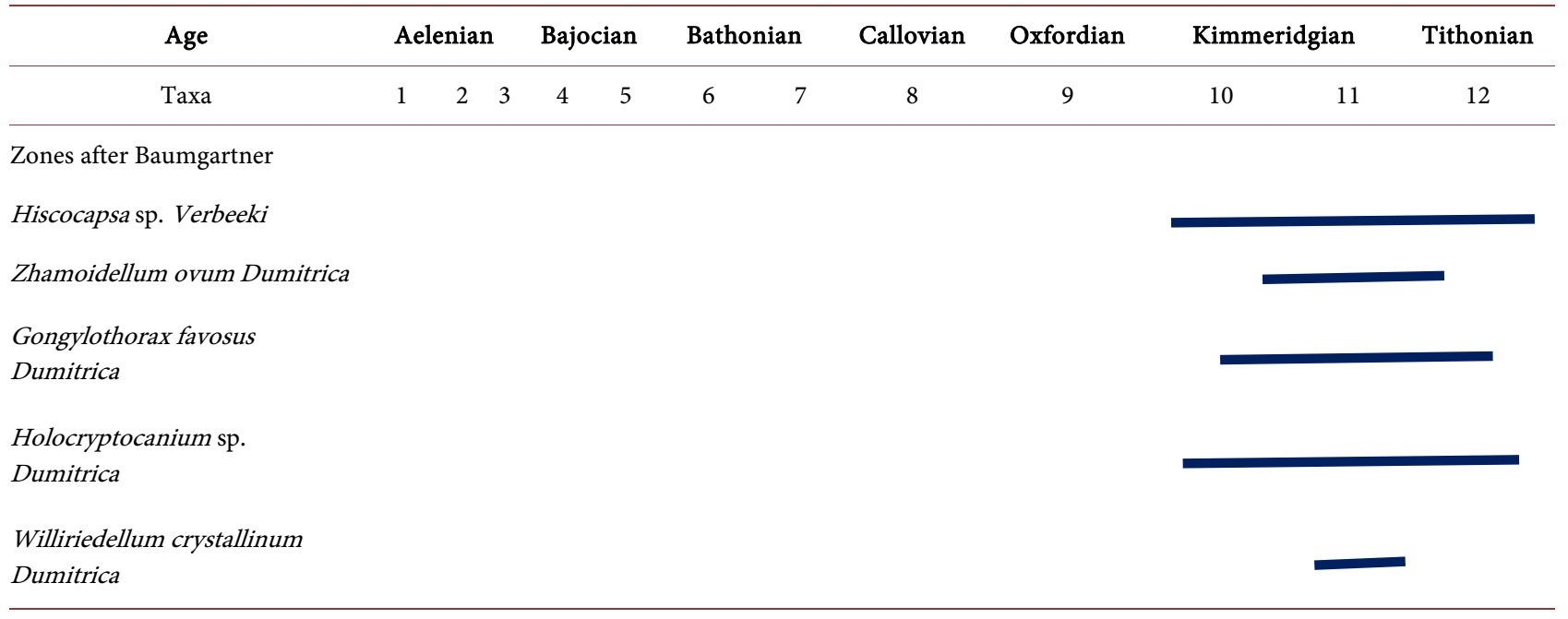




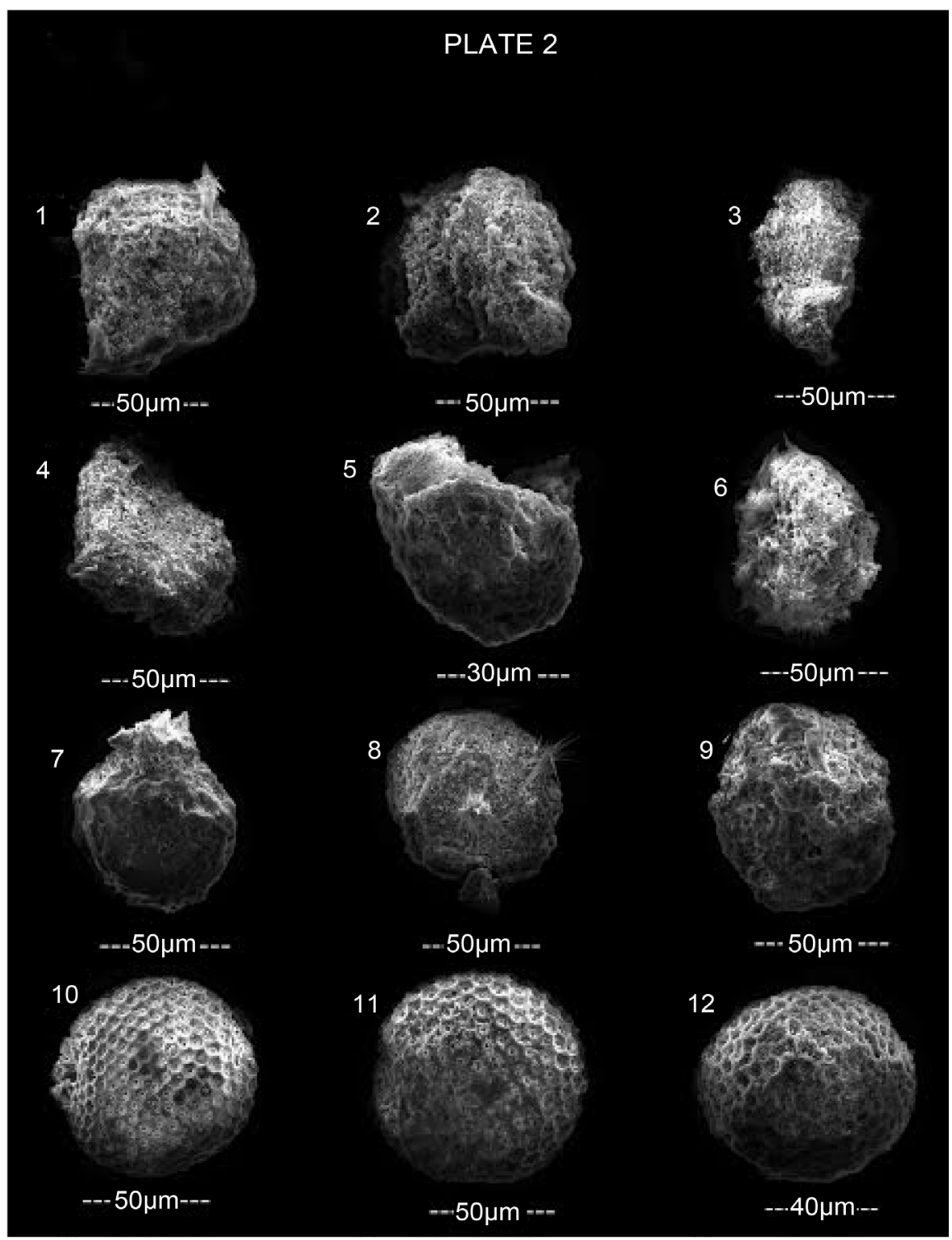

Plate 2. 1. Hiscocapsa sp. Verbeeki; 11. Holocryptocanium sp. Dumitrica; 12. Holocryptocanium sp. Dumitrica.

Kimmeridgian to mid-Tithonian assemblages, derived from cherts NHO, will provide the robust age limitations on deep-sea sedimentation. It significantly increases the average age of this region's earth's oldest deep-sea sediments, from Cretaceous [3]-Late Jurassic.

\section{Geochemistry}

Geochemical data of the pelagic sediments of cherts are shown in Figures 2-8. The research was studied in sediment geochemistry that described a weathering of the source region [19] [20] and infer the source rocks [21] [22] [23] [24] and interpretation of the tectonic settings. The concentration of the major elements in the samples studied is quite variable. The analyzed samples show a large variability in the $\mathrm{SiO}_{2}$ content. The $\mathrm{SiO}_{2}$ concentration varies between $43.75 \%$ to 


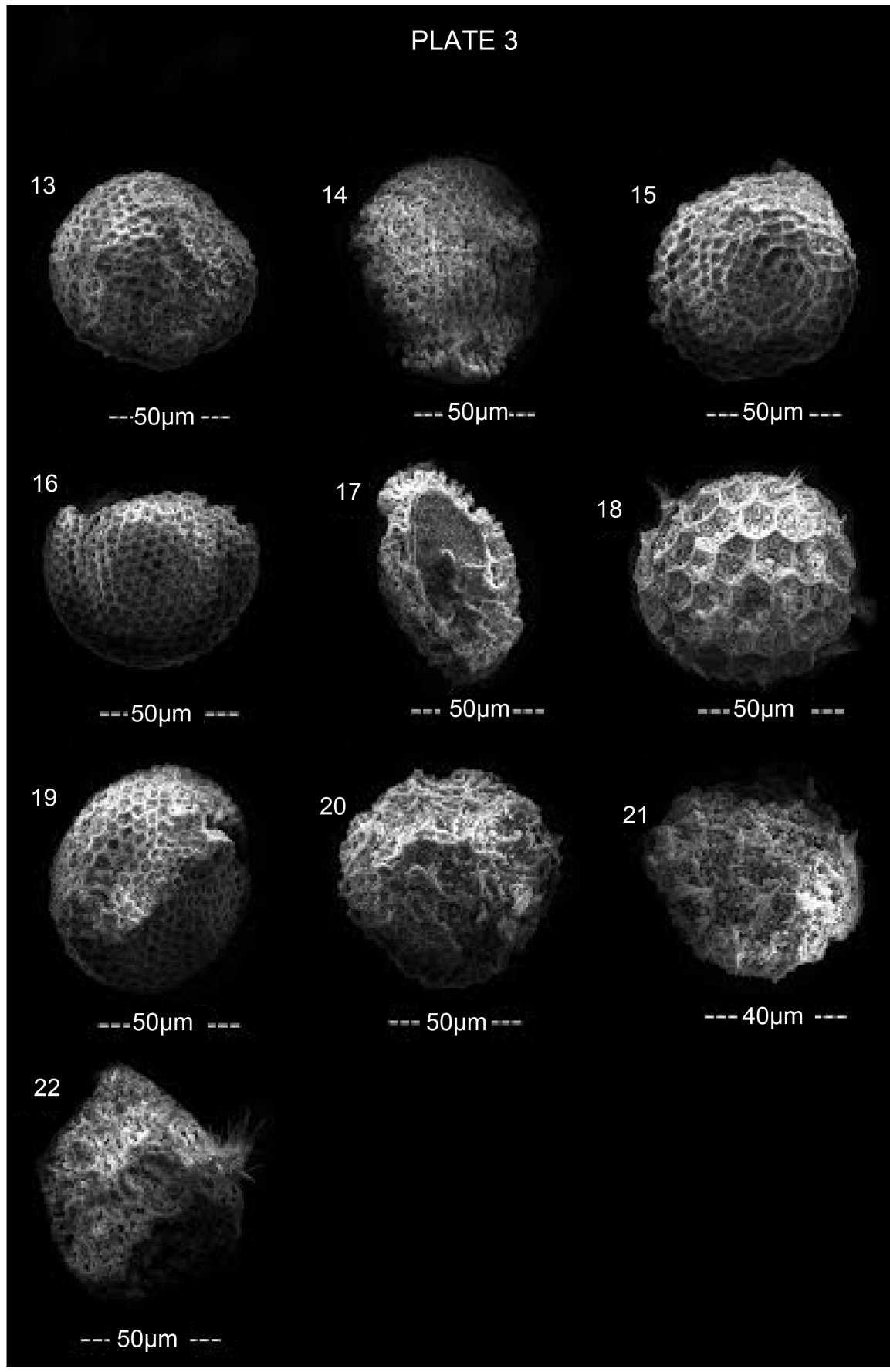

Plate 3. 13. Zhamoidellum ovum Dumitrica; 15. Zhamoidellum ovum Dumitrica; 16. Zhamoidellum ovum Dumitrica; 18. williriedellum crystallinum Dumitrica; 19. Gongylothorax favosus Dumitrica.

95.18\% with an average of $81.29 \%$. The $\mathrm{Al}_{2} \mathrm{O}_{3}$ content is observed with a maximum and minimum of (2.16\% to $15.98 \%$ with a Mean of $5.92 \%)$ and percentages of $\mathrm{CaO}$ and $\mathrm{MgO}$ are low. Most of the samples show low content of $\mathrm{Fe}_{2} \mathrm{O}_{3}$ and range from $0.87 \%$ to $11.62 \%$ with an average of $3.57 \%$. The concentration of $\mathrm{Na}_{2} \mathrm{O}$ varies from $0.09 \%$ to $2.62 \%$ with an average of $0.91 \%$. The $\mathrm{K}_{2} \mathrm{O}$ ranges from $0.18 \%$ to $2.21 \%$ with an average of $0.93 \%$. The $\mathrm{TiO}_{2}$ varies from $0.05 \%$ to 


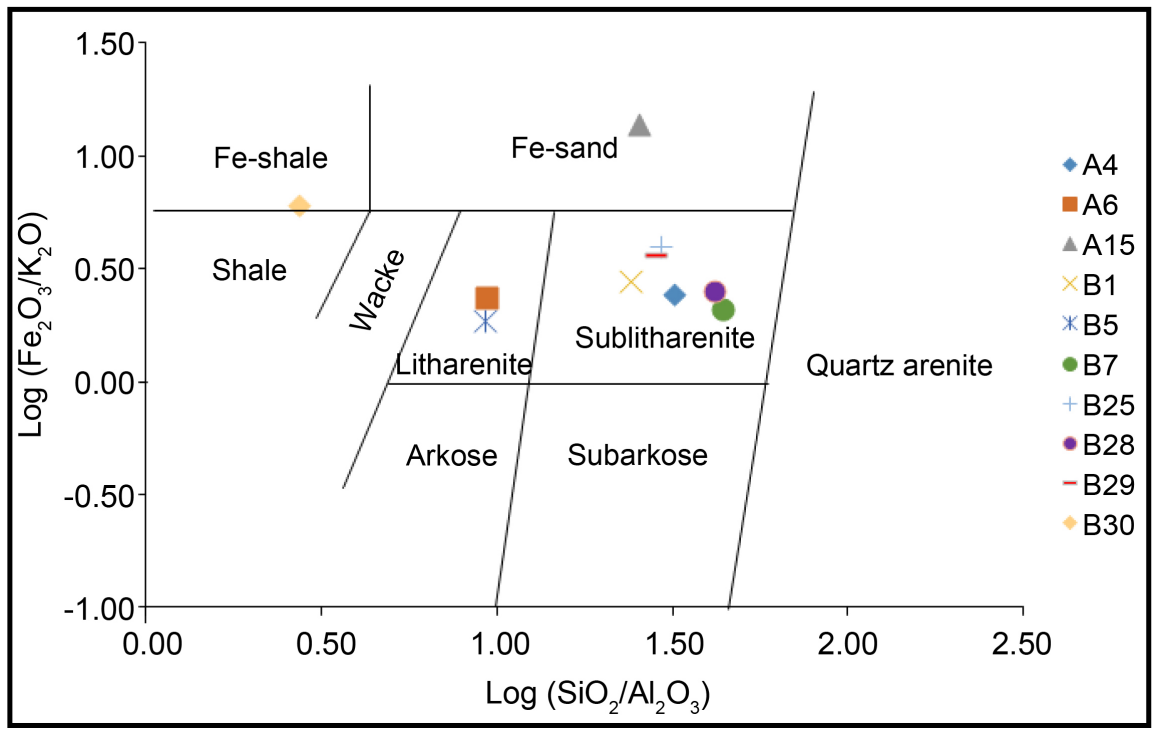

Figure 2. Geochemical classifications of the chert samples of the naga hills ophiolite using $\log \left(\mathrm{SiO}_{2} / \mathrm{Al}_{2} \mathrm{O}_{3}\right)$ vs. $\log \left(\mathrm{Fe}_{2} \mathrm{O}_{3} / \mathrm{K}_{2} \mathrm{O}\right)[25]$.

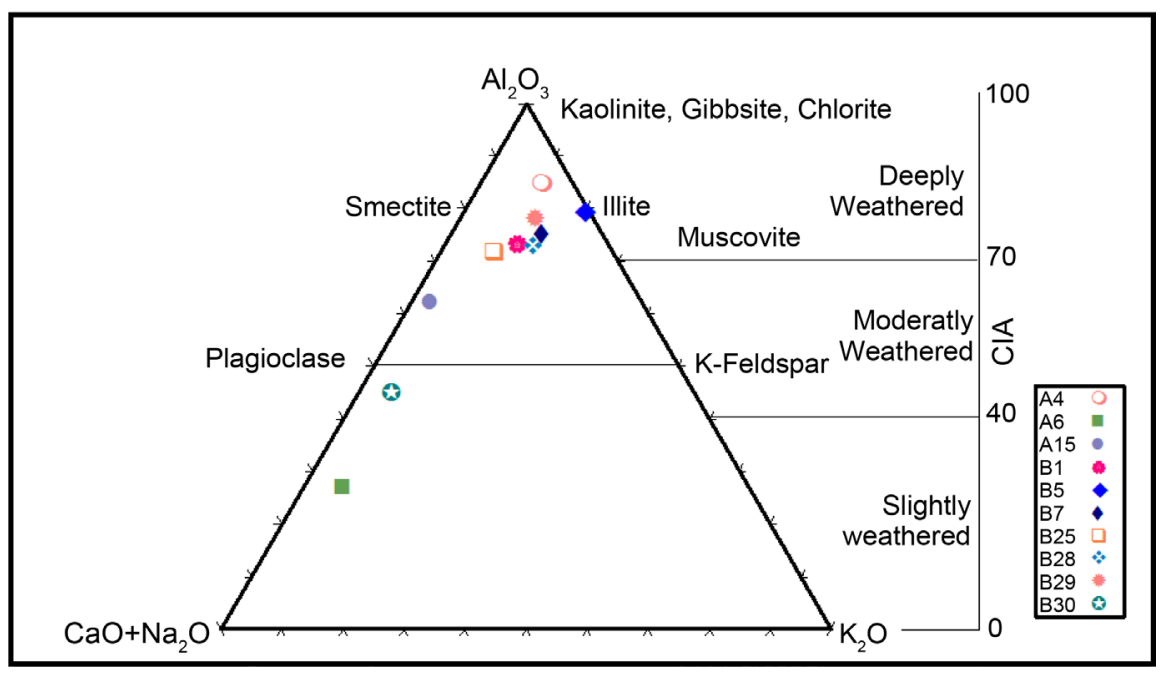

Figure 3. A-CN-K $\left(\mathrm{Al}_{2} \mathrm{O}_{3}-\mathrm{CaO}^{*}+\mathrm{Na}_{2} \mathrm{O}-\mathrm{K}_{2} \mathrm{O}\right)$ plot for Naga Hill Ophiolite chert samples for the weathering trend [30].

$1.53 \%$ with an average of $0.39 \%$. MnO shows low values and it ranges 184 from $0.03 \%$ to $0.54 \%$ with an average of $0.25 \%$. Most of the Chert samples contain a lower concentration of $\mathrm{P}_{2} \mathrm{O}_{5}$; it is ranging from $0.11 \%$ to $0.27 \%$ and a mean of $0.17 \%$. Loss of ignition (LOI) values are ranging from $0.1 \%$ to $2 \%$ and an average of $0.90 \%$.

\section{Implications on Provenance, Paleoclimate, Tectonic Settings of the Pelagic Sediments}

Our results demonstrate the radiolarian cherts samples from the NHO complex provide insight into provenance, paleoclimate, and tectonic settings. First, the provenance of classification in major elements of the analysis of this study is us- 
ing a geochemical classification diagram and in Sublitharenite, two samples in litharenite, and one sample in the Fe-shale Fe-sand region (Figure 3) [25]. Naga hills Ophiolite belts CIA values vary from $65.91 \%$ to $80.85 \%$ with an average of $74.48 \%$. The PIA values are calculated using the following equation:

PIA $=\mathrm{CIA}=\left(\mathrm{Al}_{2} \mathrm{O}_{3}-\mathrm{K}_{2} \mathrm{O}\right) \times 100 /\left(\mathrm{Al}_{2} \mathrm{O}_{3}+\mathrm{CaO}+\mathrm{Na}_{2} \mathrm{O}-\mathrm{K}_{2} \mathrm{O}\right)$. In the present study the trace element concentrations of $\mathrm{V}, \mathrm{Cr}, \mathrm{Ni}, \mathrm{Cu}, \mathrm{Zn}, \mathrm{Rb}, \mathrm{Sr}, \mathrm{Y}, \mathrm{Zr}, \mathrm{Ba}$, and $\mathrm{Pb}$ have been analyzed. The trace metal concentrations of Nickel (Ni) ranges from 155.6 to $11.24 \mathrm{ppm}$ with an average value of $57.5 \mathrm{ppm}$ and copper $(\mathrm{Cu})$ which ranges from $245.4 \mathrm{ppm}$ to $34.67 \mathrm{ppm}$ and an average value of $100 \mathrm{ppm}$. An association of radiolarian sediments with a considerable number of metallic elements such as $\mathrm{Ni}, \mathrm{Fe}, \mathrm{Mn}$, and $\mathrm{Cu}$, is suggested by the fact that the radiolarian mudstones and cherts from the abyssal seafloor contain more than 10 times as much $\mathrm{Ni}$ as the diagenetic flint nodules. Naga Hills Ophiolite has high $\mathrm{SiO}_{2}$ concentrations, and $\mathrm{Ni}, \mathrm{Cu}$, and $\mathrm{Zn}$ were abundant with an average concentration of $201.7 \mathrm{ppm}$, minimum concentrations of $25.47 \mathrm{ppm}$, and a median concentration of $87.2 \mathrm{ppm}$. These geochemical properties may indicate sulfate-reducing deposits, and the sediments were silicified during the diagenesis and termed to deposit geochemically the elements are Molybdenum, Nickel, Copper, Zinc, and organic matter abundance, underneath suboxic-anoxic conditions [26]. The concentration of Naga Hills Radiolarian Chert of Ophiolite with a high level of $\mathrm{Ni}, \mathrm{Cu}$, and $\mathrm{Zn}$ may be illustrated in an incredibly badly airy, non-restricted region that is easily subtoxic, toxic, and oxidized. Several researchers have identified weathering history and used elementary ratios in various methods to investigate the weathering of rock sources [20]. The triangular A-CN-K plot [27] also describes the sediment weathering trend. The most important basic data provide useful information about the weather conditions during the deposit of sedimentary rocks [27]. The bivariate diagram $\mathrm{Al}_{2} \mathrm{O}_{3}+\mathrm{K}_{2} \mathrm{O}+\mathrm{Na}_{2} \mathrm{O}$ differentiates the climatic conditions under which the sediments are deposited (Figure 4). The Naga hill sample shows a wide variation in $\mathrm{SiO}_{2}$ content. The majority of the sample was shown in the humid climate and a few samples fell into the area of arid conditions, which shows an increase in chemical maturity (Figure 5). Roaldset [28] distinguished between the marine and non-marine by the interaction of $\mathrm{K}_{2} \mathrm{O} / \mathrm{Al}_{2} \mathrm{O}_{3}$ and $\mathrm{MgO} / \mathrm{Al}_{2} \mathrm{O}_{3}$. The diagrams show the marine environment for the Naga Hill chert samples (Figure 6). Diagram A-CN-K demonstrates these sedimentary rocks were undergone deeply moderately weathering conditions in the source region. And only a few samples follow the A-CN-K trend and only one sample fall in the slightly weathered condition. This is also confirmed by the PIA values (plagioclase index of alteration) [29] [30].

Geochemical signatures of sediments have been used as a determination of the provenance [22] [31] [32] [33] [34] and $\mathrm{SiO}_{2} / \mathrm{Al}_{2} \mathrm{O}_{3}$ ratio is responsive to the recycling process as well as weathering and has been generally used for the insight of sediment maturity. In unaltered igneous rocks, the typical $\mathrm{SiO}_{2} / \mathrm{Al}_{2} \mathrm{O}_{3}$ ratio ranges between $\sim 3.0$ in basic and $\sim 5.0$ in acid, while in $>5.0-6.0$ [22]. A variation 


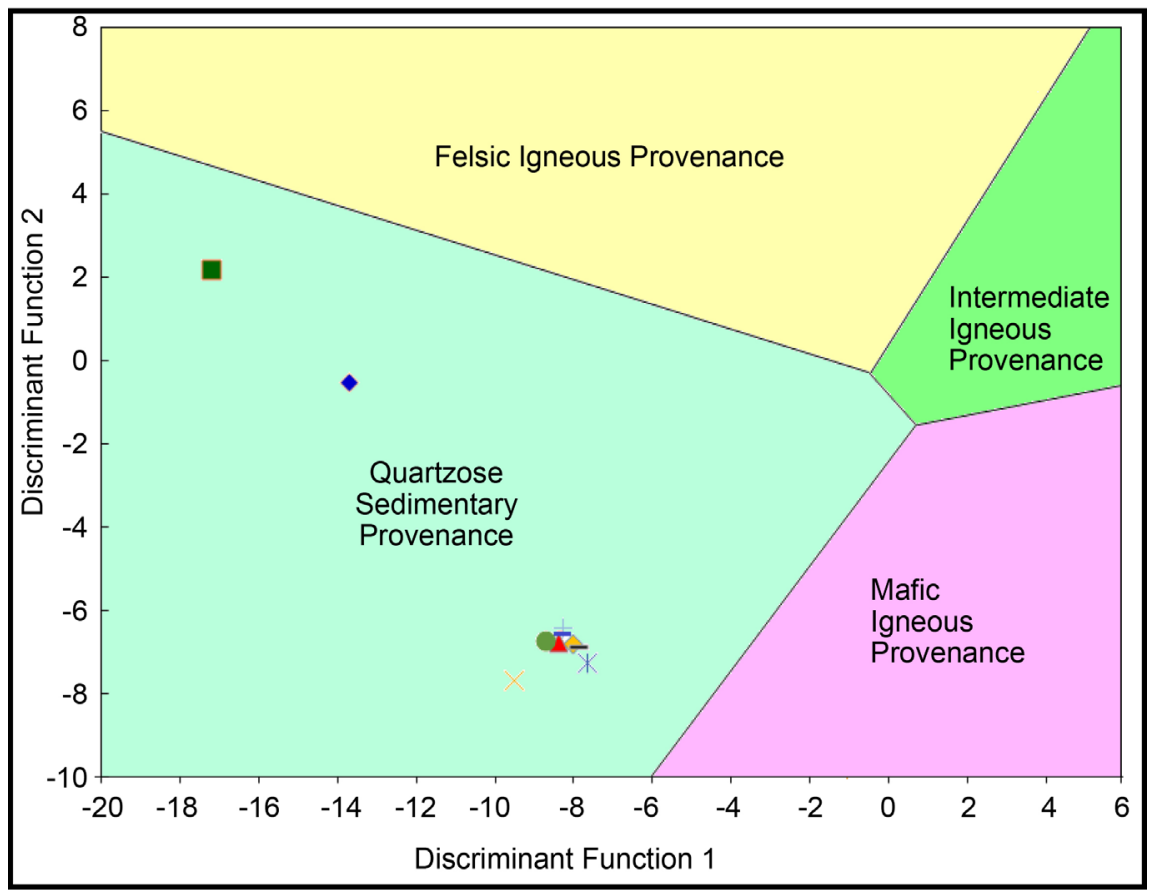

Figure 4. Discriminant function diagram for the provenance signatures of Naga Hill Ophiolite, chert suites using major elements [30].

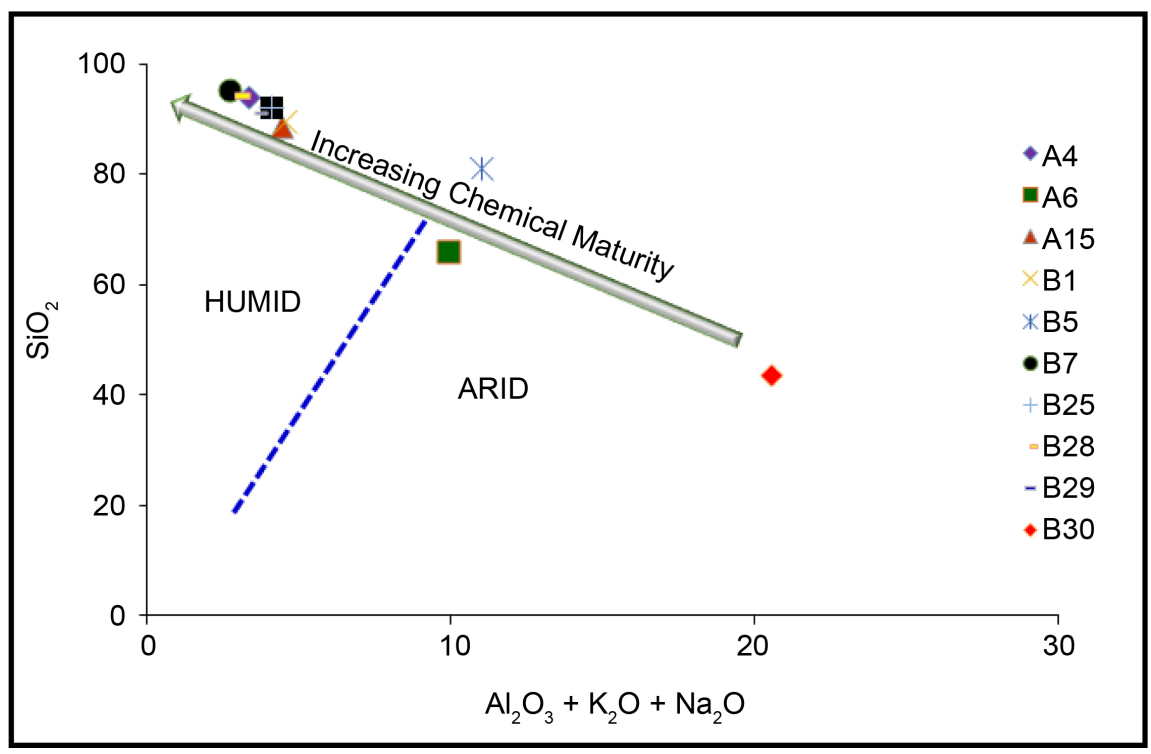

Figure 5. $\mathrm{SiO}_{2}$ vs. $\mathrm{Al}_{2} \mathrm{O}_{3}+\mathrm{K}_{2} \mathrm{O}+\mathrm{Na}_{2} \mathrm{O}$ Binary plot [27].

of the $\mathrm{SiO}_{2} / \mathrm{Al}_{2} \mathrm{O}_{3}$ ratio shows that almost all sediments are derived from sources of acidic and basic rock. The $\mathrm{SiO}_{2} / \mathrm{Al}_{2} \mathrm{O}_{3}$ ratio indicates that most of the acidic and basic source rock was derived from sediments. In this discriminant diagram, most of the samples from Naga hill occupy the sediments' source field of the quartzose (Figure 3 ) and the major oxide data from its igneous rocks are from the sedimentary quartzose provenance. The tectonic settings were calculated utilizing discriminant function, element ratio, and bivariate diagram [20] [21] [22] 


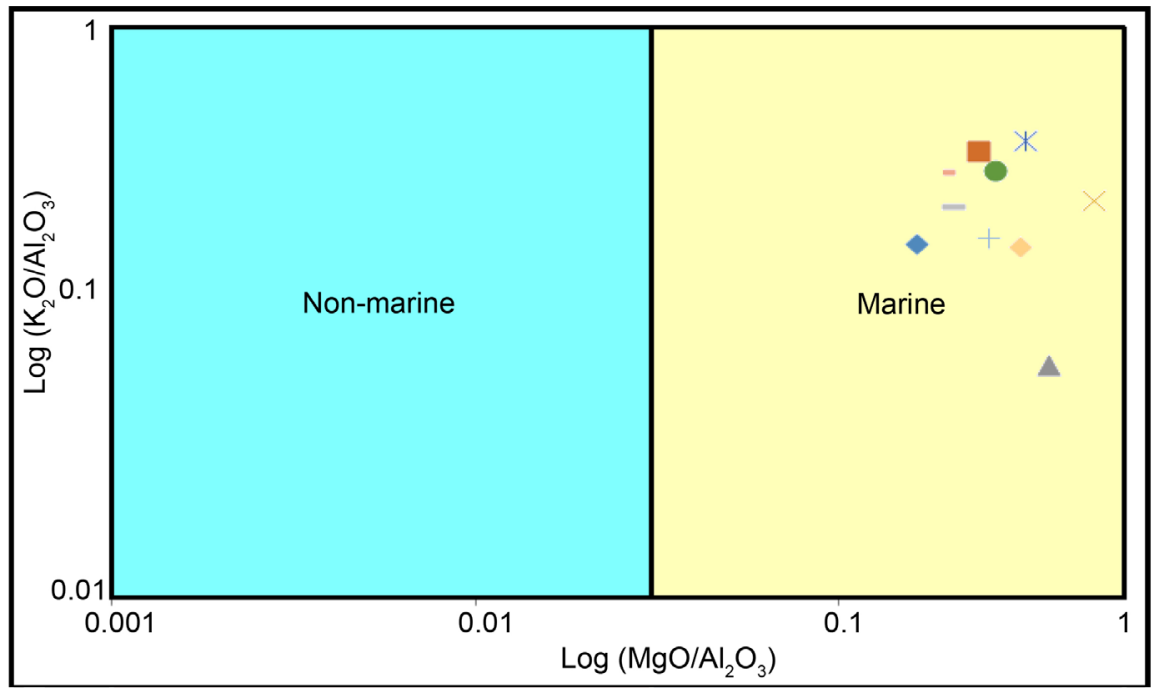

Figure 6. $\log \mathrm{K}_{2} \mathrm{O} / \mathrm{Al}_{2} \mathrm{O}_{3}$ vs. $\log \mathrm{MgO} / \mathrm{Al}_{2} \mathrm{O}_{3}$ plots Diagram depicting the depositional environment of the Naga Hills Ophiolite [28].

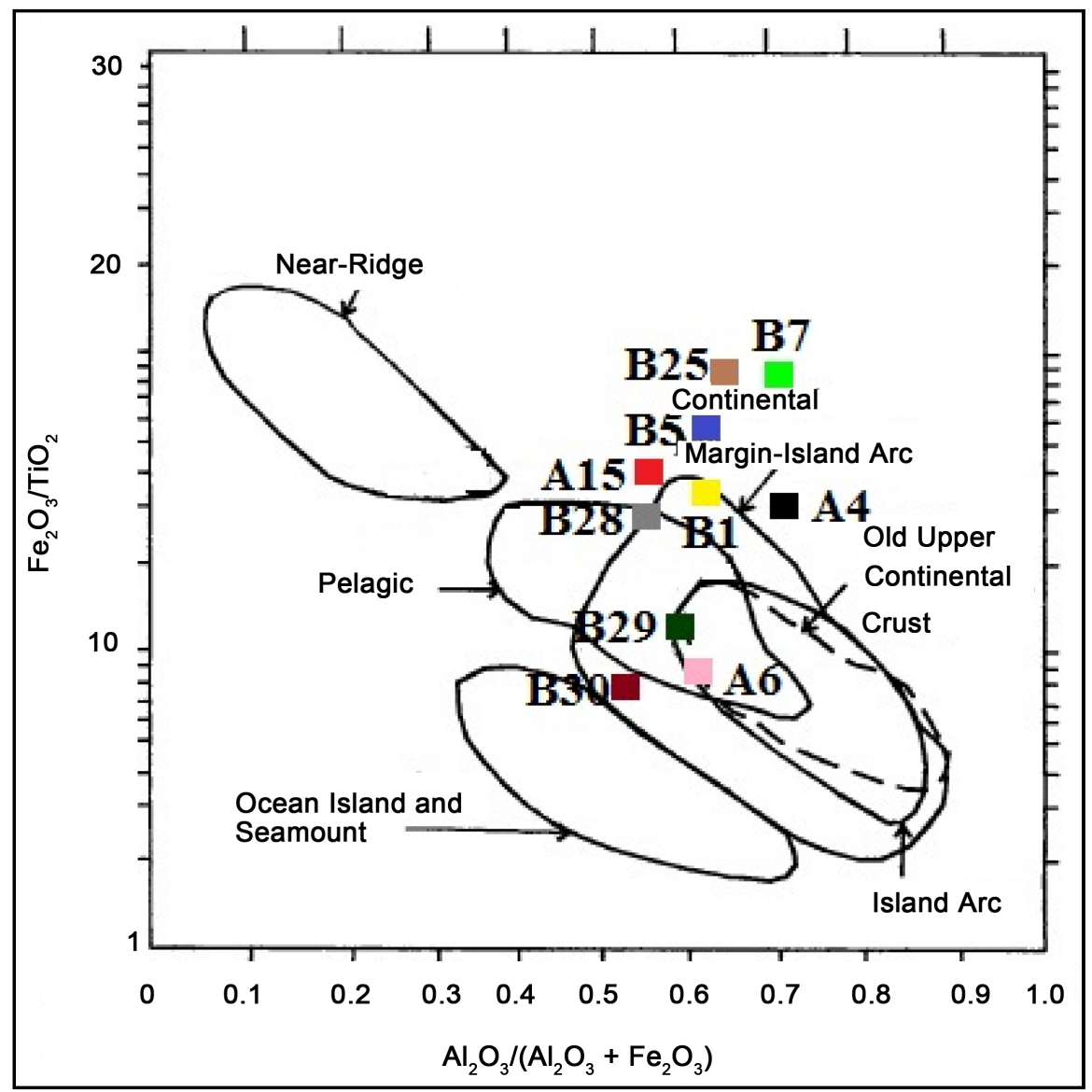

Figure 7. Geochemical data of cherts plot on $\mathrm{Fe}_{2} \mathrm{O}_{3} / \mathrm{TiO}_{2}$ vs. $\mathrm{Al}_{2} \mathrm{O}_{3} /\left(\mathrm{Al}_{2} \mathrm{O}_{3}+\mathrm{Fe}_{2} \mathrm{O}_{3}\right)$ discrimination diagram Samples from Naga Hills Ophiolite [38].

[35] [36] [37] [38]. They used $\mathrm{CaO}$ and LOI free basins and adjusted the data to $100 \%$ to demarcate various field boundaries [34] [38] [39]. Most Chert samples 


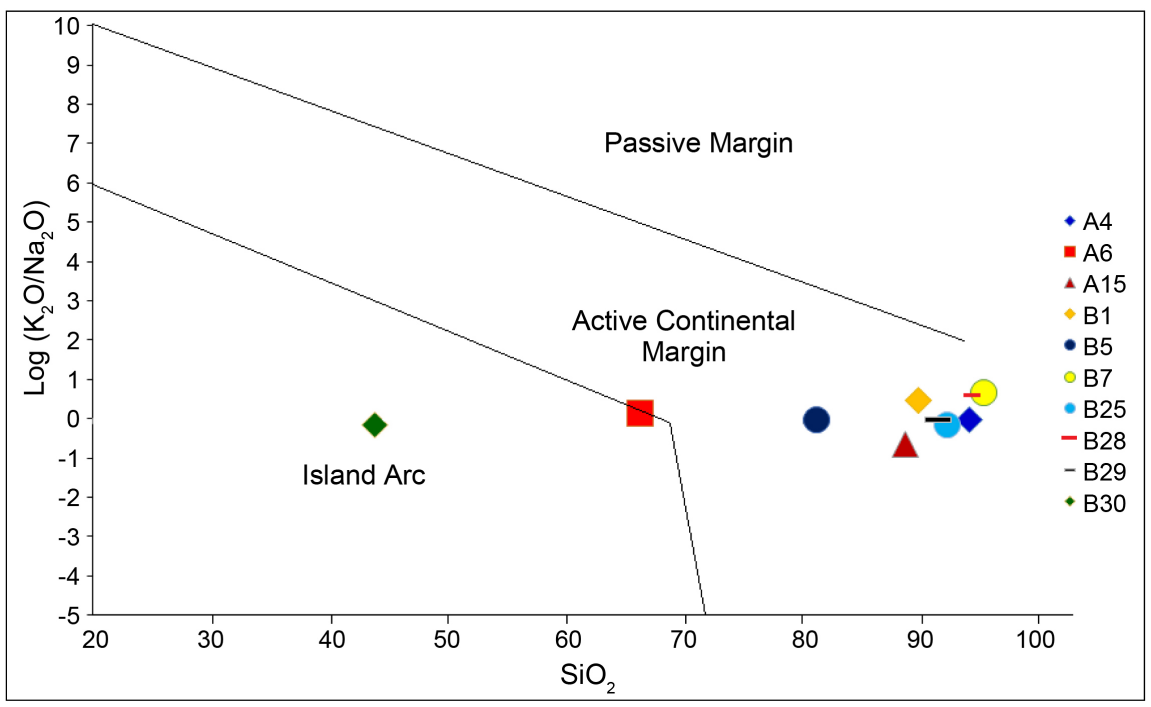

Figure 8. $\log \left(\mathrm{K}_{2} \mathrm{O} / \mathrm{Na}_{2} \mathrm{O}\right)$ vs. $\mathrm{SiO}_{2}$ discrimination diagram of chert samples showing Active Continental Margin; field boundary coordinates derived from [31].

only fall on the active continental margin and another sample collapses in the field of the island arc (Figure 6), which implies the deposition of volcanic rocks measurements on the Naga hill chert in the Active continental settings. Another supporting diagram of geochemical data of the Cherts plot in the $\mathrm{Fe}_{2} \mathrm{O} / \mathrm{TiO}_{2}$ vs. $\mathrm{Al}_{2} \mathrm{O}_{3} /\left(\mathrm{Al}_{2} \mathrm{O}_{3}+\mathrm{Fe}_{2} \mathrm{O}\right)$ discrimination diagram (Figure 7) shows the most continental margin island arc and old upper continental crust [38]. [31] proposed a discriminating diagram using $\log \left(\mathrm{K}_{2} \mathrm{O} / \mathrm{Na}_{2} \mathrm{O}\right)$ vs. $\mathrm{SiO}_{2}$ to establish various tectonic settings of clastic rocks (Figure 8).

\section{Conclusion}

The present study using the pelagic sediments from red chert samples from Naga Hills ophiolite was carried out for geochemical and Micropaleontological studies. This shows that the iron-rich chert samples are rich in pelagic micro-organisms, i.e. Radiolarians. The chert comprises various radiolarian skeletons which are contained in a silica matrix in the form of cryptocrystalline quartz crystals. They are inserted into the silicate clay matrix with iron-rich minerals. The disappearance of pelagic calcite and the very low calcium content of the chert indicate that the chert is lower in the compensatory depth at which more calcite dissolves within the ocean. Five (5) radiolarians were identified and distributed in Naga hills Ophiolite namely Zhamoidellum ovum dumitrica, gongylothorax favosus dumitrica, Williriedellum kristallinum dumitrica, Hiscocapsa sp. Holocryptocanium sp. and Verbeeki sp. dumitrica has age supremacy ranging between Kimmeridgian and mid-Tithonian. Geochemical data of pelagic sediments in the NHO samples showed the provenance of the rocks are sublitharenite, Litharenite, Fe-shale, and $\mathrm{Fe}$-sand field, and the A-CN-K, discrimination plots indicated the deep to moderate weather conditions and quartzose sedimentary provenance in the source region for these sediments. The tectonic settings of chert samples illustrated the 
marine environment of $\mathrm{NHO}$ and the diagram of $\log \left(\mathrm{K}_{2} \mathrm{O} / \mathrm{Na}_{2} \mathrm{O}\right)$ vs. $\mathrm{SiO}_{2}$, for the determination of various tectonic-adjusting chert samples, only one sample drop in the field of the active margin falls inside this area of the island arc, implying that the tectonic setting of the Naga Hills has been deposited in the active continental margin.

\section{Acknowledgements}

The first author Dr. Ramamoorthy Ayyamperumal thanks to DST INSPIRE Fellowship (Ref.No.dst/inspire/IF140775/Dated.06.12.2014) New Delhi, India for financially supported for this research work. I would like thanks to the Department of Geology, University of Madras, Guindy Campus, Chennai, Tamilnadu, India. The State Administration of Foreign Experts Affairs (SAFEA) provided financial support for RAMAMOORTHY AYYAMPERUMAL academic visit to Lanzhou University. The first author is grateful to the Key Laboratory of western China's Environmental system, College of earth, and environmental sciences for being a post-doctoral researcher (Award No: 252813, dated 10/04/2020).

\section{Conflicts of Interest}

The authors declare no conflicts of interest regarding the publication of this paper.

\section{References}

[1] Ghose, N.C., Chatterjee, N. and Fareeduddin (2014) A Petrographic Atlas of Ophiolite. Springer, Berlin. https://doi.org/10.1007/978-81-322-1569-1

[2] Acharyya, S.K. (2010) Tectonic Evolution of Indo-Burma Range with Special Reference to Naga-Manipur Hills. Memoirs of the Geological Survey of India, 75, 25-43.

[3] Acharyya, S.K. (1986) Tectono-Stratigraphic History of the Naga Hills. Ophiolites. In: Mitra, N.D., Acharyya, S.K., Datta, A.K., Ghosh, S., Nandy, D.R., Roy, D.K., Vidyadharan, K.T., Venkataramana, P., Srivastava, R.K., Bhattacharyya, S., Joshi, A., Jena, S.K. and Goswami, H.K., Eds., Geology of Nagaland Ophiolite, D. B. Ghosh Memorial Volume Geological Survey of India Memoirs, 119, 94-103.

[4] Acharyya, S.K. (1990) Tectonics of the Ophiolite Belt from Naga Hills and the Andaman Islands, India. Proceedings of the Indian Academy of Sciences-Earth \& Planetary Sciences, 99, 187-199.

[5] Acharyya, S.K. (2007) Collisional Emplacement History of the Naga-Andaman Ophiolites and the Position of the Eastern Indian Suture. Journal of Asian Earth Sciences, 29, 229-242. https://doi.org/10.1016/j.jseaes.2006.03.003

[6] Evans, P. (1964) The Tectonic Framework of Assam. Journal of the Geological Society of India, 5, 80-96.

[7] Uddin, A., Kumar, P. and Sarma, J.N. (2007) Early Orogenic History of the Eastern Himalayas: Compositional Studies of Paleogene Sandstones from Assam, Northeast India. International Geology Review, 49, 798-810. https://doi.org/10.2747/0020-6814.49.9.798

[8] Ramamoorthy, A. (2015) Petrography and Provenance of Surface Barail Sandstones, Kohima, Nagaland. International Journal of Latest Technology Engineering and Ap- 
plied Science, 4, 35-41.

[9] Ramamoorthy, A. (2016) Petrography and Heavy Mineral Analysis of Barail Sandstones, Zubza Village, Kohima District, Nagaland India. International Journal Geology and Earth Sciences, 2, 43-53.

[10] Srivastava, S.K. (2018) Petrography and Major Element Geochemistry of II Paleogene Sandstones, Kohima Town, Nagaland. Applied Geochemistry, 20, 41-49.

[11] Ghosh, S., Chattopadhyay, B., Roy, D.K. and Venkataramana, P. (1984) On the Radiolaria-Bearing Rocks of Naga Hills Ophiolite. Records of the Geological Survey of India, 113, 89-97.

[12] Capotondi, L., Bonomo, S., Budillon, G., Giordano, P. and Langone, L. (2020) Living and Dead Benthic Foraminiferal Distribution in Two Areas of the Ross Sea (Antarctica). Rendiconti Lincei di Scienze Fisiche e Naturali, 31, 1037-1053. https://doi.org/10.1007/s12210-020-00949-z

[13] Rimoldi, B., et al. (2007) Deep Sea Turbidites in Brine-Filled Anoxic Basins of the Mediterranean Ridge. Depositional Models Based on Sedimentological and Geochemical Characterization. Rendiconti Lincei, 18, 27-47. https://doi.org/10.1007/BF02967143

[14] Pessagno, E.A. and Newport, R.L. (1972) A Technique for Extracting Radiolaria from Radiolarian Cherts. Micropaleontology, 18, 231-234. https://doi.org/10.2307/1484997

[15] Norrish, K. and Hutton, J.T. (1969) An Accurate X-Ray Spectrographic Method for the Analysis of a Wide Range of Geological Samples. Geochimica et Cosmochimica Acta, 33, 431-453.

[16] Giles, T.R., Lawn, V.M. and Wary, G.F. (1995) Surf Geology and Drift Exploration Studies in the Tsacba Lake and Chedakuz Creek Areas (93F/2,7), Central British Columbia. In: Grant, B. and Newell, J.M., Eds., Geological Fieldwork 1994, B.C. Ministry of Energy, Mines, and Petroleum, Resources, Paper 1995-1, 199-205.

[17] Baxter, A.T. (2011) Upper Jurassic Radiolarians from the Naga Ophiolite, Nagaland, Northeast India. Gondwana Research, 20, 638-644.

https://doi.org/10.1016/j.gr.2011.02.001

[18] Baxter, A.T., Aitchison, J.C., Ali, J.R. and Zyabrev, S.V. (2010) Early Cretaceous Radiolarians from the Spongtang Massif, Ladakh, NW India: Implications for NeoTethyan Evolution. Journal of the Geological Society of London, 167, 511-517. https://doi.org/10.1144/0016-76492009-099

[19] Baumgartner, P.O., O’Dogherty, L., Gorican, S., Urquhart, E., Pillevuit, A. and DeWever, P. (1995) Middle Jurassic to Lower Cretaceous Radiolarian of Tethys: Occurrences, Systematics, Biochronology. Mémoires de Géologie, Universite de Lausanne, 23, 1172 .

[20] Madhavaraju, J., Ramírez-Montoya, E., Monreal, R., González-León, C.M., Pi-Puig, T., Espinoza-Maldonado, I.G. and Grijalva-Noriega, F.J. (2016) Paleoclimate, Paleoweathering and Paleoredox Conditions of Lower Cretaceous Shales from the Mural Limestone, Tuape Section, Northern Sonora, Mexico: Constraints from Clay Mineralogy and Geochemistry. Revista Mexicana de Ciencias Geológicas, 33, 34-48.

[21] Tawfik, H.A., Ghandour, I.M., Maejima, W., Armstrong-Altrin, J.S. and Abdel-Hameed, A.M.T. (2017) Petrography and Geochemistry of the Siliciclastic Araba Formation (Cambrian), East Sinai, Egypt: Implications for Provenance, Tectonic Setting, and Source Weathering. Geological Magazine, 154, 1-23. https://doi.org/10.1017/S0016756815000771

[22] Armstrong-Altrin, J.S. (2015) Evaluation of Two Multi-Dimensional Discrimination 
Diagrams from the Beach and Deep-Sea Sediments from the Gulf of Mexico and Their Application to Precambrian Clastic Sedimentary Rocks. International Geological Review, 57, 1446-1461. https://doi.org/10.1080/00206814.2014.936055

[23] Armstrong-Altrin, J.S., Nagarajan, R., Madhavaraju, J., Rosales-Hoz, L., Lee, Y.I., Balaram, V., Cruz-Martinez, A. and Avila-Ramirez, G. (2013) Geochemistry of the Jurassic and Upper Cretaceous Shales from the Molango Region, Hidalgo, Eastern Mexico: Implications for Source-Area Weathering, Provenance, and Tectonic Setting. Comptes Rendus Geoscience, 345, 185-202.

https://doi.org/10.1016/j.crte.2013.03.004

[24] Dai, S., Graham, I.T. and Ward, C.R. (2016) A Review of Anomalous Rare Earth Elements and Yttrium in Coal. International Journal of Coal Geology, 159, 82-95. https://doi.org/10.1016/j.coal.2016.04.005

[25] Zaid, S.M. (2017) The Provenance of Coastal Dune Sands along the Red Sea, Egypt. Journal of Earth System Science, 126, 50. https://doi.org/10.1007/s12040-017-0825-z

[26] Herron, M.M. (1988) Geochemical Classification of Terrigenous Sands and Shales from the Core or Log Data. Journal of Sediment Petrology, 58, 820-829. https://doi.org/10.1306/212F8E77-2B24-11D7-8648000102C1865D

[27] Kametaka, M. (2005) Sedimentary Environments 365 of the Middle Permian Phosphorite-Chert Complex from the Northeastern Yangtze Platform, China; the Gufeng Formation: A Continental Shelf Radiolarian Chert. Sedimentary Geology, 174, 197-222. https://doi.org/10.1016/j.sedgeo.2004.12.005

[28] Suttner, L.J. and Dutta, P.K. (1986) Alluvial Sandstone Composition and Paleoclimate, Framework Mineralogy. Journal of Sedimentary Petrology, 56, 329-345. https://doi.org/10.1306/212F8909-2B24-11D7-8648000102C1865D

[29] Roaldest, E. (1978) Mineralogical and Chemical Changes during Weathering, Transportation, and Sedimentation in Different Environments with Particular References to the Distribution of Yttrium and Lanthanide Elements. Ph.D. Thesis, Geological Institute, The University of Oslo, Oslo.

[30] Fedo, C.M., Nesbitt, H.W. and Young, G.M. (1995) Unraveling the Effects of K-Metasomatism in Sedimentary Rocks and Paleosols with Implications for Palaeoweathering Conditions and Provenance. Journal of Geology, 23, 921-924. https://doi.org/10.1130/0091-7613(1995)023<0921:UTEOPM>2.3.CO;2

[31] Nesbitt, H.W. and Young, G.M. (1982) Early Proterozoic Climates and Plate Motions Inferred from Major Element Chemistry of Lutites. Nature, 299, 715-717. https://doi.org/10.1038/299715a0

[32] Roser, B.P. and Korsch, R.J. (1986) Determination of Tectonic Setting of SandstoneMudstone Suites Using $\mathrm{SiO}_{2}$ Content and $\mathrm{K}_{2} \mathrm{O} / \mathrm{Na}_{2} \mathrm{O}$ Ratio. Journal of Geology, 94, 635-650. https://doi.org/10.1086/629071

[33] Roser, B.P. and Korsch, R.J. (1988) Provenance Signatures of Sandstone Mudstone suites Determined Using Discrimination Function Analysis of Major Element Data. Chemical Geology, 67, 119-139. https://doi.org/10.1016/0009-2541(88)90010-1

[34] Madhavaraju, J. and Ramasamy, S. (2002) Petrography and Geochemistry of Late Maastrichtian-Early Paleocene Sediments of Tiruchirapalli Cretaceous, Tamil Nadu-Paleoweathering and Provenance Implications. Journal of Geological Society of India, 59, 133-142.

[35] Zaid, S.M. (2017) Petrography and Geochemistry of the Middle Miocene Gebel El Rusas Sandstones, Eastern Desert, Egypt: Implications for Provenance and Tectonic Setting. Journal of Earth System Science, 126, 103.

https://doi.org/10.1007/s12040-017-0873-4 
[36] Hernandez-Hinojosa, V., Montiel-Garcia, P.C., Armstrong-Altrin, J.S., Nagarajan, R. and Kasper-Zubillaga, J.J. (2018) Textural and Geochemical Characteristics of Beach Sands along the Western Gulf of Mexico, Mexico. Carpathian Journal of Earth Environmental Sciences, 13, 161-174. https://doi.org/10.26471/cjees/2018/013/015

[37] Tawfik, H.A., Salah, M.K., Maejima, W.J., Armstrong-Altrin, J.S., Abdel-Hameed, A.T., El Ghandour, M.M. and Ruffell, A. (2018) Petrography and Geochemistry of the Lower Miocene Moghra Sandstones, Qattara Depression, North Western Desert, Egypt. Arabian Journal of Geosciences, 53, 1938-1953.

https://doi.org/10.1002/gj.3025

[38] Verma, S.P. and Verma, S.K. (2018) Petrogenetic and Tectonic Implications of Major and Trace Element and Radiogenic Isotope Geochemistry of Pliocene to Holocene Rocks from the Tacaná Volcanic Complex and Chiapanecan Volcanic Belt, Southern Mexico. Lithos, 312, 274-289. https://doi.org/10.1016/j.lithos.2018.05.016

[39] Murray, R.W. (1994) Chemical Criteria to Identify the Depositional Environment of Chert: General Principles and Applications. Sedimentary Geology, 90, 213-232.

https://doi.org/10.1016/0037-0738(94)90039-6 